Cite this article:

Lombardo G, Pardo A,

Mascellaro A, Corrocher $G$,

Marincola M, Costantinescu FE,

Nocini PF.

Rehabilitation of severely resorbed maxillae with zygomatic implants:

a literature review.

Stoma Edu J. 2015;2(1):70-79

\section{REHABILITATION OF SEVEREIY RESORBED MAXILLAE WITH ZYGOMATIC IMPLANTS: A LITERATURE REVIEW}

https://doi.org/10.25241/stomaeduj.2015.2(1).art.9

\section{Giorgio Lombardo $0^{1 a^{*}}$, Alessia Pardo ${ }^{\text {th, }}$ Anna Mascellaro'c, Giovanni Corrocher' Mauro Marincola ${ }^{2 e}$, Florin-Eugen Costantinescu ${ }^{3 f}$, Pier Francesco Nocini ${ }^{19}$}

${ }^{1}$ Clinic of Dentistry and Maxillofacial Surgery, University of Verona, Verona, Italy State University of Cartagena, Cartagena, Colombia ${ }^{3}$ Holistic Dental Medical Institute-ROPOSTURO Bucharest, Romania

a. MD, DDS, Associate Professor b. Dental Hygienist c. Dentistry Student d. DDS, MSC

e. MD, DDS, Clinical Assistant Professor f. DDS, PhD Student g. MD, DDS, Full Professor, Director
Background: The use of endosseous implants is a routine treatment modality for replacing missing teeth. However, the use of dental implants is limited by the presence of adequate bone volume permitting their anchorage. Several bone augmentation techniques have been applied to solve this problem. During the last two decades zygomatic implants have become a proposed alternative to bone augmentation procedures for the severely atrophic maxilla. The main advantages of this kind of rehabilitation could be that bone grafting may not be needed and a fixed prosthesis could be applied sooner. Objective: The purpose of this review is to examine the evidence concerning the management of severely resorbed edentulous maxillae using implants placed in the zygomatic bone.

Data collection: The articles reported in this literature review were searched on pubmed/medline database, considering only the English-written scientific journals.

Outcomes: A Zygomatic Success Code, describing criteria to score the success of a rehabilitation anchored on zygomatic implants, is represented by the outcomes of these variables: implant stability, associated sinus pathology, peri-implant soft tissues condition and prosthetic results. Excellent results were observed for zygomatic implants. Many studies showed an implant survival rate of $100 \%$ combined to similar prosthetic results.The cumulative survival rate (CSR) and patients' satisfaction indicate that zygomatic implants could be an effective alternative for the management of an atrophic maxilla and, in some cases, be the only treatment solution. However, there are no well-defined criteria that help the clinician to evaluate this prosthetic rehabilitation.

Conclusions: Thus, further studies are necessary to assess the longterm prognosis of the zygoma implant and whether these implants offer some advantages over other techniques for treating atrophic maxillae.

Keywords: atrophic maxilla, zygomatic implants, dental implants, surgical technique, implants success criteria
Received: May, $5^{\text {th }} 2015$ Accepted: June $2^{\text {nd }} 2015$

* Corresponding author:

Associate Professor Giorgio Lombardo, MD, DDS Clinic of Dentistry and Maxillofacial Surgery University of Verona P.le L.A. Scuro 10 I-37134 Verona, Italy Tel: +390458124867 Fax: +390458124865 e-mail: giorgio.lombardo@univr.it

\section{BACKGROUND}

The use of endosseous implants is currently a routine treatment modality for prosthetic reconstruction of the edentulous maxilla, allowing to achieve acceptable long-term results in patients with sufficient bone volume (1). However, inadequate bone volume can be the result of a resorption process following teeth extraction, traumatic injuries, odontogenous infections and maxillary sinus pneumatisation (2-4), which present challenges to implant rehabilitation. Many techniques have been applied to increase the bone volumes. The most studied were sinus floor augmentation, onlay bone grafting, Le Fort I osteotomy with interpositional bone grafting and free revascularized flaps (5-14). However these treatment protocols may extend the overall treatment time, the need for hospitalization and the inability to wear a pre-existing prosthesis during the healing period. Additionally, increased 


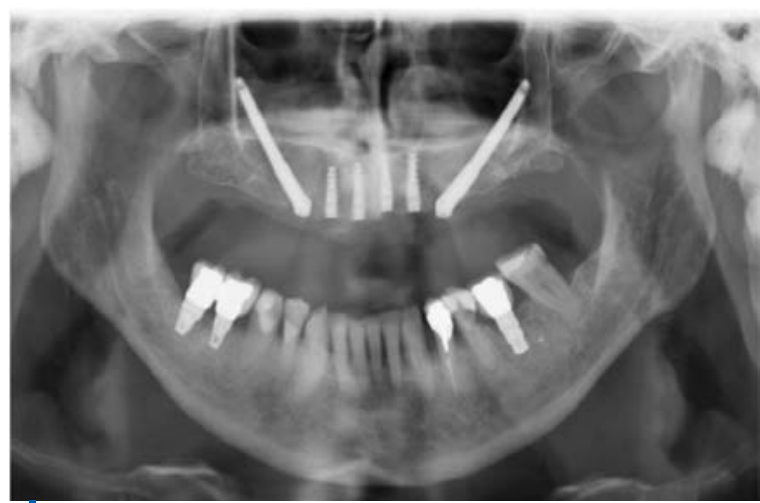

Figure 1. Postoperative panoramic x-ray

failure rates have been experienced in situations with inadequate bone volume and density in edentulous patients $(4,15,16)$.

These problems reduce the patient's compliance and may lead to refusal of treatment. Therefore, during the last two decades the placement of dental implants in the zygomatic bone process has become a proposed alternative to bone augmentation procedures.

The clinical procedure for placement of zygomatic implants was first described by Brånemark (Nobel Biocare, Göteborg, Sweden) to provide the clinician with an alternative to grafting procedures. After their initial clinical use in patients with maxillary resection for malignant diseases (17), the indication of zygomatic implants was expanded to completely edentulous patients with severe maxillary atrophy (18). The bone of the zygomatic arch was used for anchorage of a long implant and, together with conventional implants, could be used as an anchor for epistheses, prosthesis and/or obturators (19).

In clinical practice, zygomatic implants have been used in association to conventional implants or alone. The first protocol proposed involved the placement of a minimum of 2 premaxillary implants in the canine position, or ideally 4 premaxillary implants in the canine and the central incisor positions, allowing for the fabrication of fixed hybrid prostheses (20). After that, Bothur et all. (21) proposed the use of prosthesis full supported by multiple zygomatic implants (Fig. 1-2).

The technique provides many patients with a

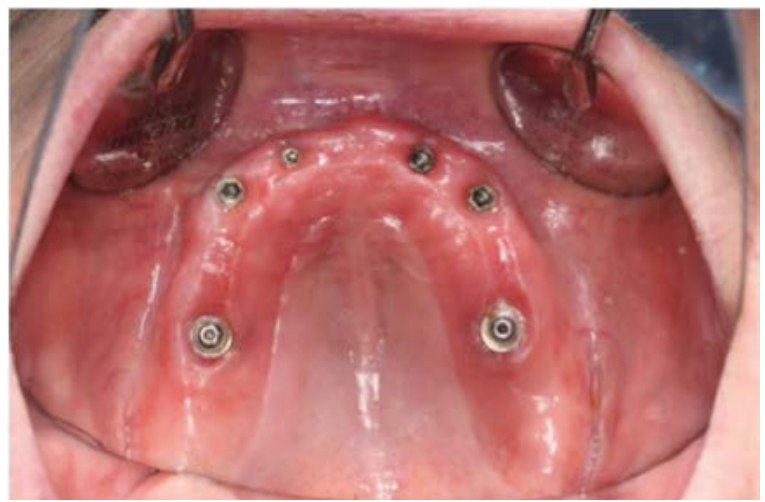

Figure 3. The mixed technique

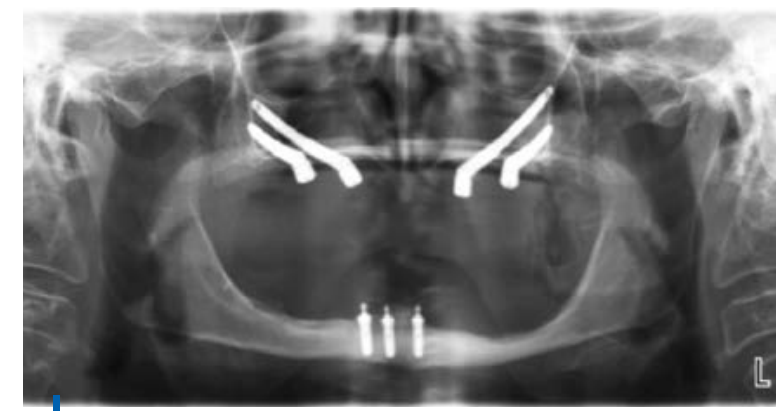

Figure 2. Postoperative panoramic x-ray

restored function, improving their esthetic and social life. Bedrossian (22) distinguished three zones in the upper maxilla to provide a decisional flowchart: zone 1, the premaxilla: zone 2, the premolar area: zone 3, the molar area (Table 1).

In case of an adequate bone in zone 1 and bilateral lack of bone in zones 2 and 3, two to four conventional implants are distribuited in the anterior maxilla plus one zygomatic implant on each premolar/molar side. This is the so-called mixed technique (Fig. 3). Conventional implants placed in the premaxilla probably reduce the load applied to the zygomatic implants and the effectiveness of this mixed rehabilitation is dependent on a rigid connection between implants (18). Particularly, there is a significant biomechanical disadvantage regarding the long lever arm and the small amount of bone integration and the biomechanics of these implants could be improved by inserting angled implants connected to conventional fixtures (23) and reducing the distal cantilever (24). Moreover the angle head of the zygomatic implant is designed to allow the placement of the prosthesis at $45^{\circ}$ to the long axis of the implant, minimizing the lever effect (20).

Instead, in case of lack of bone in all three zones of the maxilla, four zygomatic implants can be used for the rehabilitation. In this option, the "QUAD technique", zygomatic implants are used alone and placed in an arch form to counteract the bending forces (25). Four implants, two on each side, can restore the entire dental arch: the anterior ones rehabilitate the incisor-canine region, whereas

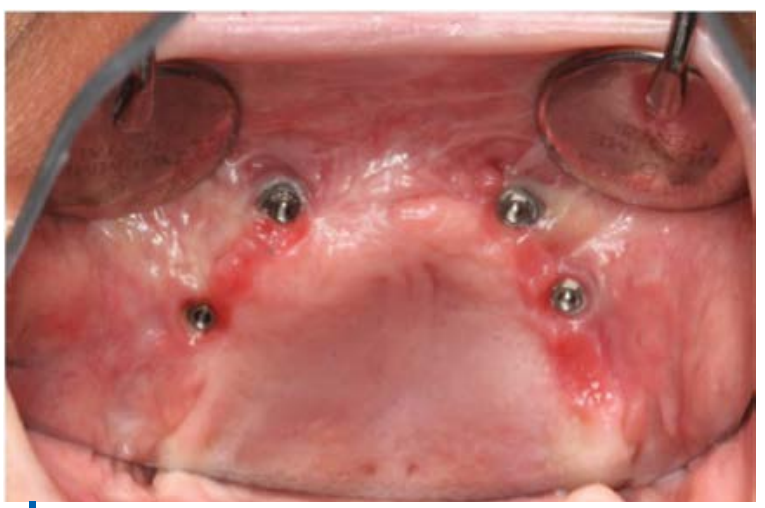

Figure 4. The "QUAD" technique 
Table 1. Treatment recommendations based on the presence of bone in the different zones of the maxilla

\begin{tabular}{|c|c|}
\hline Presence of bone & Surgical approach \\
\hline Zones I, II and III & Traditional, axial, implants \\
\hline Zones I and II & Four traditional implants, tilted \\
\hline Zones I only & Zygomatic implants plus two or four traditional implants \\
\hline Insufficient bone & Four zygomatic implants \\
\hline
\end{tabular}

Table 2. Zygomatic Success Code

\begin{tabular}{|c|c|c|c|c|}
\hline Criteria & $\begin{array}{c}\text { Condition I } \\
\text { Success grade I }\end{array}$ & $\begin{array}{c}\text { Condition II } \\
\text { Success grade II }\end{array}$ & $\begin{array}{c}\text { Condition III } \\
\text { Success garde III }\end{array}$ & $\begin{array}{l}\text { Condition IV } \\
\text { Failure }\end{array}$ \\
\hline $\begin{array}{l}\text { Criterion A: zygomatic } \\
\text { implant stability }\end{array}$ & $\begin{array}{l}\text { No mobility } \\
\text { No pain }\end{array}$ & $\begin{array}{l}\text { Light clinical mobility } \\
\text { No pain }\end{array}$ & $\begin{array}{l}\text { Clear clinical mobility } \\
=\text { no evidence of } \\
\text { disintegration of the } \\
\text { apical part of the } \\
\text { implant or rotation } \\
\text { No pain }\end{array}$ & $\begin{array}{l}\text { Clear clinical mobility } \\
\quad=\text { evidence of } \\
\text { disintegration of the } \\
\text { apical part of the implant } \\
\text { Rotation and/or pain }\end{array}$ \\
\hline $\begin{array}{c}\text { Criterion B: } \\
\text { Associated sinus } \\
\text { pathology }\end{array}$ & $\begin{array}{l}\text { Lanza \& Kennedy } \\
\text { test - } \\
\text { Lund-Mackay } \\
\text { score }=0\end{array}$ & $\begin{array}{l}\text { Lanza \& Kennedy test - } \\
\text { Lund-Mackay score } \\
=0\end{array}$ & $\begin{array}{l}\text { Lanza \& Kennedy test - } \\
\text { Lund-Mackay score } \\
>0\end{array}$ & $\begin{array}{l}\text { Lanza \& Kennedy test + } \\
\text { Lund-Mackay score }>0\end{array}$ \\
\hline $\begin{array}{l}\text { Criterion C: peri- } \\
\text { implant soft tissue } \\
\text { condition }\end{array}$ & No recession & $\begin{array}{l}\text { Light recession } \\
\text { Implant head is visible } \\
=\text { yuxta-gingival } \\
\text { No exposed threads }\end{array}$ & $\begin{array}{c}\text { Recession } \\
\text { Up to seven exposed } \\
\text { threads }\end{array}$ & $\begin{array}{l}\text { Recession. } \\
\text { More than seven } \\
\text { exposed threads }\end{array}$ \\
\hline $\begin{array}{c}\text { Criterion D: prosthetic } \\
\text { offset }\end{array}$ & $\begin{array}{l}0 \mathrm{~mm} \leq \mathrm{D} \leq 6 \mathrm{~mm} \\
-3 \mathrm{~mm} \leq \mathrm{D} \leq 0 \mathrm{~mm}\end{array}$ & $\begin{array}{l}6 \mathrm{~mm}<D \leq 10 \mathrm{~mm} \\
-4 \mathrm{~mm} \leq \mathrm{D}<-3 \mathrm{~mm}\end{array}$ & $\begin{array}{c}10 \mathrm{~mm}<\mathrm{D} \leq 15 \mathrm{~mm} \\
-5 \mathrm{~mm} \leq \mathrm{D}<-4 \mathrm{~mm}\end{array}$ & $\begin{array}{l}D>15 \mathrm{~mm} \\
D<-5 \mathrm{~mm}\end{array}$ \\
\hline
\end{tabular}

the posterior zygomatic implants can restore the second premolar/first molar (Fig. 4).

The main indications for this type of implant are:

1) Patients with extensive defects of the maxilla caused by tumour-resections $(17,26)$;

2) History of periodontitis (27);

3) Traumatic injuries, cleft lip and palate and congenital defects $(20,27-29)$;

4) Failure of previous maxillary rehabilitations (30).

Contraindications to the use of zygomatic implants include (19):

1) Acute sinus infections;

2) Maxillary or zygoma pathology;

3) Uncontrolled or malignant systemic disease.

Relative contraindications are:

1) Chronic infectious sinusitis

2) The use of bisphosphonates
3) Smoking more than 20 cigarettes a day For these reasons, accurate pre-surgical evaluations are required before the placement of the zygomatic implants.

\section{DATA COLLECTION}

The articles reported in this literature review were searched on pubmed/medline database, considering only the English-written scientific journals; case reports and review studies were excluded.

The keywords selected were "Zygoma Implants", "Rehabilitation", "Survival" and "Results". After this research only 17 works presented the characteristics described above. 
Table 3. Sinus complications in studies in which zygomatic implants were placed using the two-stage protocol

\begin{tabular}{|c|c|c|c|c|}
\hline Two-stage protocol & Patients (n) & $\begin{array}{l}\text { Follow-up period } \\
\text { (months) }\end{array}$ & $\begin{array}{c}\text { Survival rate of } \\
\text { zygomatic implants \% }\end{array}$ & Sinusitis \% \\
\hline $\begin{array}{l}\text { Malevez } \\
\text { et al.(2004) }\end{array}$ & 55 & $6-48$ & 100 & $5(9)$ \\
\hline $\begin{array}{l}\text { Hirsch } \\
\text { et al.(2004) }\end{array}$ & 76 & 12 & 98 & $3(4)$ \\
\hline $\begin{array}{c}\text { Becktor } \\
\text { et al.(2005) }\end{array}$ & 16 & $9-69$ & 90.3 & $6(26.6)$ \\
\hline $\begin{array}{c}\text { Farzad } \\
\text { et al.(2006) }\end{array}$ & 11 & $18-56$ & 100 & $1(9.1)$ \\
\hline $\begin{array}{c}\text { Davo } \\
\text { et al.(2009) (53) }\end{array}$ & 24 & 60 & 97.4 & $5(20.8)$ \\
\hline $\begin{array}{c}\text { Stièvenart } \\
\text { et al.(2010)(54) }\end{array}$ & 10 (of 20) & 40 & 96.3 & $1(1.3)$ \\
\hline $\begin{array}{c}\text { Aparicio } \\
\text { et al.(2012) }\end{array}$ & 22 & 120 & 97.7 & $2(9.1)$ \\
\hline
\end{tabular}

Table 4. Sinus complications in studies in which zygomatic implants were placed using the immediate function protocol

\begin{tabular}{|c|c|c|c|c|}
\hline $\begin{array}{l}\text { Immediate } \\
\text { function protocol }\end{array}$ & $\begin{array}{c}\text { Total number of } \\
\text { patients }\end{array}$ & $\begin{array}{l}\text { Follow-up period } \\
\text { (months) }\end{array}$ & $\begin{array}{l}\text { Survival rate of zygomatic } \\
\text { implants \% }\end{array}$ & Sinusitis \% \\
\hline $\begin{array}{l}\text { Aparicio } \\
\text { et al. (2004) }\end{array}$ & 20 & $6-48$ & 100 & 0 \\
\hline $\begin{array}{l}\text { Mozzati } \\
\text { et al. (2008) }\end{array}$ & 7 & 24 & 100 & 0 \\
\hline
\end{tabular}

\section{OUTCOMES}

The severely atrophied maxilla constitues a therapeutic problem for a restorative dentist, especially when previously performed rehabilitations result in failure and patients' dissatisfaction. The zygomatic implants were introduced to solve prosthetic reconstruction problems in fully edentulous patients.

The zygomatic implant is a titanium endosteal implant ranging from $30 \mathrm{~mm}$ to $52.5 \mathrm{~mm}$ in length. The apical two thirds of the implant is $4 \mathrm{~mm}$ in diameter and the alveolar one third is $5 \mathrm{~mm}$ in diameter. The surgical technique for inserting zygomatic implants has been the subject of modification during the last years, with today essentially two major variations existing: the internal and the external approach. In the first option, the sinus membrane is carefully dissected and the implant is inserted internal to the maxillary sinus as reported by Brånemark and colleagues (31). The extrasinusal technique is characterized by inserting the implant external to the maxillary sinus before anchoring in the zygomatic bone. In this case the implant is covered only by soft tissue along its lateral maxillary surface. The decision for an "external" rather than an "internal" placement of the zygomatic implant must be the result of accurate anatomic assessments. For this reason Aparicio et al. (32) proposed a classification for zygomatic implant patient based on the zygoma anatomy guided approach: the ZAGA approach. It is a modification of the original zygomatic implant technique and it focuses on interindividual anatomic differences. Thus, the path of the implant body can vary from being totally intrasinus to being totally extrasinus, depending on the relationship between the different anatomic components.

Keller et al. (10) and Branemark et al. (31) suggested that zygomatic implants may be used as an alternative to bone grafts in case of severe maxillary resorption, because the insertion of these implants does not require additional surgery. This major surgical technique requires a proper training and many studies were conducted in an institutional environment, such universities or specialty clinics. The presurgical protocols provide for the selection and preparation of patients in order to allow promising results. Once the clinical examination is complete, radiographic examinations are performed to ensure appropriate treatment planning of the zygomatic implants.

The presurgical exams recommended are following: 
Table 5. Peri-implant diseases in studies in which zygomatic implants were placed using the immediate function protocol or the two-stage protocol

\begin{tabular}{|c|c|c|c|c|c|c|c|}
\hline $\begin{array}{c}\text { Study } \\
\text { (reference) }\end{array}$ & $\begin{array}{l}\text { Patients } \\
\text { (n) }\end{array}$ & $\begin{array}{c}\text { Zygoma } \\
\text { implants } \\
\text { (n) }\end{array}$ & $\begin{array}{l}\text { Follow-up } \\
\text { period } \\
\text { (months) }\end{array}$ & $\begin{array}{c}\text { Patients } \\
\text { affected by } \\
\text { peri-implant } \\
\text { pathology }\end{array}$ & $\begin{array}{c}\text { Number of } \\
\text { zygomatic } \\
\text { implants with } \\
\text { peri-implant } \\
\text { diseases }\end{array}$ & $\begin{array}{l}\text { Patients in } \\
\text { which the } \\
\text { situation was } \\
\text { resolved }\end{array}$ & Treatment \\
\hline $\begin{array}{l}\text { Al-Nawas } \\
\text { et al.(2004) }\end{array}$ & 14 & 20 & 20 & ? & 9 & ? & ? \\
\hline $\begin{array}{l}\text { Hirsch } \\
\text { et al.(2004) }\end{array}$ & 76 & 124 & 12 & $\begin{array}{c}8 \text { especially } \\
\text { on the palatal } \\
\text { surface }\end{array}$ & $?$ & $?$ & $?$ \\
\hline $\begin{array}{l}\text { Miglioranca } \\
\text { et al.(2011) }\end{array}$ & 75 & 150 & $\geq 12$ & $?$ & 2 & $?$ & $?$ \\
\hline $\begin{array}{l}\text { Rodriguez } \\
\text { et al.(2014) }\end{array}$ & 29 & 67 & 20 & $?$ & 4 & $?$ & $?$ \\
\hline $\begin{array}{l}\text { Malò } \\
\text { et al.(2015) }\end{array}$ & 352 & 747 & $6-84$ & 54 & 54 & 43 & $\begin{array}{c}\text { Scaling + CHXI } \\
\text { antibiotics or } \\
\text { surgery }\end{array}$ \\
\hline
\end{tabular}

Table 6. Prosthetic results reported in studies in which zygomatic implants were placed using the immediate function protocol or the two-stage protocol

\begin{tabular}{|cccc|}
\hline $\begin{array}{c}\text { Study } \\
\text { (reference) }\end{array}$ & Patients $(\mathrm{n})$ & $\begin{array}{c}\text { Follow-up } \\
\text { (months) }\end{array}$ & 100 \\
\hline $\begin{array}{c}\text { Becktor } \\
\text { et al.(2005) }\end{array}$ & 16 & $9-69$ & 100 \\
\hline $\begin{array}{c}\text { Farzad } \\
\text { et al.(2006) }\end{array}$ & 11 & $18-56$ & 100 \\
\hline $\begin{array}{c}\text { Mozzati } \\
\text { et al.(2008) }\end{array}$ & 7 & 24 & 100 \\
\hline $\begin{array}{c}\text { Miglioranca } \\
\text { et al.(2011) }\end{array}$ & 75 & $\geq 12$ & 100 (12 \\
\hline
\end{tabular}

- Cone Beam Computed Tomography (CBCT)

- Panoramic images

- Intraoral radiographs

- Lateral cephalograms

Especially, computed tomography is crucial for the evaluation of the zygomatic implant site, the sinus status and the implant path (19).

In literature different surgical protocols were reported and Le Fort I, crestal and palatal incisions resulted the most commonly applied approaches. These techniques provided excellent prosthetic stabilization $(33,34)$.

Analysing complications described in literature, $(1,22,35-41)$ the main adverse reactions related to zygomatic implants were caused by sinus pathologies, poor oral hygiene, implant mobility and inadequate prosthetic rehabilitation. Specifically a Zygomatic Success Code (Table 2 ), describing criteria to score the success of a rehabilitation anchored on zygomatic implants, is represented by the outcomes of the previous variables (19): implant stability, associated sinus pathology, peri-implant soft tissues condition and prosthetic results. The success grade of the implant is determined by the worst condition of the four criteria.

The percentage of sinus pathology in clinical studies has been reported by many authors (Table 3-4). In particular, Becktor et al. (1) in a 3 years and 10 months study, reported on 16 patients consecutively treated with 31 zygomatic implants and 74 additional dental implants. Six patients were affected by sinusitis. Three patients had bilateral sinus infection and another three unilateral. It occurred both early and later in the period after the abutment connection surgery. They were treated with antibiotics and sinus rinses. Three zygomatic implants failed because medications have did not solve the infection. One patient was treated for sinusitis throughout the observation periods. Farzad et al. (42) described experiences of 11 patients treated consecutively who received zygomatic implants. Two patients reported a maxillary sinus discomfort after surgery, but it resolved spontaneously. 
Table 7. Reported zygomatic implant outcome

\begin{tabular}{|c|c|c|c|c|c|c|}
\hline $\begin{array}{c}\text { Study } \\
\text { (reference) }\end{array}$ & $\begin{array}{l}\text { Follow-up } \\
\text { (months) }\end{array}$ & Patients (n) & $\begin{array}{l}\text { Zygoma } \\
\text { implants }\end{array}$ & $\begin{array}{l}\text { Conventional } \\
\text { implants }\end{array}$ & $\begin{array}{c}\text { CSR\% } \\
\text { Zygoma } \\
\text { implants }\end{array}$ & $\begin{array}{c}\text { CSR\% } \\
\text { Conventional implants }\end{array}$ \\
\hline $\begin{array}{l}\text { Bedrossian et al. } \\
\qquad(2002)\end{array}$ & 34 & 22 & 44 & 80 & 100 & 91.25 \\
\hline $\begin{array}{l}\text { Hirsch } \\
\text { et al. (2004) }\end{array}$ & 12 & 76 & 145 & $?$ & 97.9 & $?$ \\
\hline $\begin{array}{l}\text { Malevez } \\
\text { et al.(2004) }\end{array}$ & $6-48$ & 55 & 103 & 194 & 100 & 91.75 \\
\hline $\begin{array}{c}\text { Becktor } \\
\text { et al.(2005) }\end{array}$ & 46.4 & 16 & 31 & 74 & 90.3 & 95.9 \\
\hline $\begin{array}{c}\text { Farzad } \\
\text { et al.(2006) }\end{array}$ & $18-46$ & 11 & 22 & 42 & 100 & 97.7 \\
\hline $\begin{array}{l}\text { Aparicio } \\
\text { et al.(2006) }\end{array}$ & 60 & 69 & 131 & 304 & 100 & 99 \\
\hline $\begin{array}{l}\text { Peñarrocha } \\
\text { et al.(2007) }\end{array}$ & 12 & 23 & 44 & $?$ & 97.7 & $?$ \\
\hline $\begin{array}{l}\text { Fernández } \\
\text { et al.(2014) }\end{array}$ & 27 & 95 & 244 & $?$ & 99.5 & $?$ \\
\hline $\begin{array}{l}\text { Aparicio } \\
\text { et al.(2010) }\end{array}$ & $7-38$ & 25 & 47 & 127 & 100 & 100 \\
\hline $\begin{array}{l}\text { Fernández } \\
\text { et al.(2014) }\end{array}$ & 27 & 95 & 244 & $?$ & 99.5 & $?$ \\
\hline $\begin{array}{c}\text { Malò } \\
\text { et al.(2015) }\end{array}$ & $6-84$ & 352 & 747 & 795 & 98.2 & 97.9 \\
\hline
\end{tabular}

However, with a third patient this sinus problem was not resolved spontaneously and a nasal antrostomy was performed. After surgery, the patient did not complain of any symptoms anymore. Bedrossian et al. (43) did not observe sinusitis during their study. As discussed in literature, it is likely that problems with sinusitis are related more to the extreme thinness of the palatal bone tissue and the consequent oro-antro communications, than to exposed implant threads, to the surgical procedure and to the micro-movement of the functioning zygomatic implant $(1,39,44-46)$.

Complications in the soft tissues may occur with this type of implants (Table 5). Malò et al. (47) reported the outcome of rehabilitating 352 patients with complete edentulous atrophied maxillae using 747 zygomatic implants. Periimplant pathology, such as higher probing pocket depths together with bleeding on probing and/ or presence of dental plaque, were observed in 54 patients and 54 implants. The situations were resolved for 43 patients by means of non surgical or surgical interventions. With 11 patients the inflammation persisted. As discussed by Aparicio (19), one concern may be the long-term effect of having exposed threads towards the soft tissues at the lateral aspect of the zygomatic implants. However, Miglioranca (18) did not report irritation or inflammation of the soft tissues despite a dehiscence in the cervical portion of the implant was observed. This was directly related to the strict control protocol with periodic professional hygiene in which every patient enrolled in that study was included. Based on anatomic reasons, especially the lateral aspect of the zygomatic implant body in the coronal and middle thirds covered only with soft tissue, the maintenance of a good standard of oral hygiene was suggested in most studies.

Another zygomatic implant complications may be the clinical mobility. Aparicio et al. (19) described slight mobility when extra-sinusally placed implants are tested individually. This non-rotational movement is due to the elastic modulus of the zygomatic bone when bent by a remotely applied force and it disappeared when implants were splinted together. In case of a rotational movement an implant failure should be considered.

The success of the zygomatic prosthesis and the patients' satisfaction described in literature were encouraging $(1,42,48)$ (Table 6). 
However, anatomic measurements to assess the position of the head of the zygomatic implant with regard to the middle of the crest of the alveolar ridge should be included $(1,19)$. The posterior palatal position seems to create difficulties in upholding hygiene by patients and a bulky dental bridge sometimes can lead to discomfort and/or speech problems.

A particular advantage of this type of implants is the possible shortening of the treatment time which could be achieved with immediate or early loading. Studies that used immediate zygomatic implant loading reported decreased treatment times and increased acceptance of the treatment by the patient $(35,40,44)$. However, owing to the small number of patients enrolled and the short follow-up times, further studies are necessary to confirm these results (24).

One of the prerequisites for immediate or early loading is high initial implant stability (24). The special properties of treated-surface implants, TiUnite Nobel Biocare, may have contributed to the favorable results of many studies (49). Their micropores and properties similar to ceramics ensure a high osteoconductivity and rapid anchoring to the newly bone formation (50). The failure rate described in literature was not related to the number of zygomatic implants but, probably, to poor oral hygiene and soft tissue contamination surrounding the abutments $(1,48)$. A strict control protocol is important to observe because the soft tissues may act as a bacterial reservoir (38). Furthermore, Al Nawas et al. reported that the probing pocket depth increased even in absence of bleeding and pathological colonization. This indicates a non-infectious cause of the soft tissue alteration probable.

Finally, an excellent survival rate was observed for zygomatic implants in cases of prosthetic rehabilitation of patients with maxillary resorption (Table 7). Many studies showed an implant survival rate of $100 \%$ combined to similar prosthetic results $(20,24,42,44,47,48,51,52)$.

\section{CONCLUSIONS}

In conclusion, the cumulative survival rate and patients' satisfaction indicate that zygomatic implants could be an effective alternative for the management of an atrophic maxilla and, in some cases, be the only treatment solution.

The survival rates of these particular implants may be related to suitable presurgical examinations and surgical procedures, whereas their failures reported in some studies are more related to local infection than the number of zygomatic implants.

Particularly, if a zygomatic rehabilitation is used a proper skilled surgical technique is required and regular recalls are essential to allow long term successful results.

However, despite numerous positive zygomatic implants outcomes, there are no well-defined criteria that help the clinician to evaluate the success of a rehabilitation supported by these implants.

Thus, further studies are necessary to assess the long-term prognosis of the zygoma implant.

\section{Conflict of Interests}

The authors declare that there is no conflict of interests regarding the publication of this paper.

\section{Bibliography}

1. Becktor JP, Isaksson S, Abrahamsson P, Sennerby L. Evaluation of 31 zygomatic implants and 74 regular dental implants used in 16 patients for prosthetic reconstruction of the atrophic maxilla with cross-arch fixed bridges. Clin Implant Dent Relat Res. 2005;7(3):159-165.

2. Adell R, Eriksson B, Lekholm U, Branemark PI, Jemt T. Long-term follow-up study of osseointegrated implants in the treatment of totally edentulous jaws. Int J Oral Maxillofac Implants. 1990;5(4):347-359.

3. Tolman DE, Laney WR. Tissue-integrated prosthesis complications. Int J Oral Maxillofac Implants. 1992; 7(4):477-484.

4. Jemt $T$, Lekholm U. Implant treatment in edentulous maxillae: a 5-year follow-up report on patients with different degrees of jaw resorption. Int J Oral Maxillofac Implants. 1995;10(3):303-311. 5. Becktor JP, Hallström H, Isaksson S, Sennerby $\mathrm{L}$. The use of particulate bone grafts from the mandible for maxillary sinus floor augmentation before placement of surface-modified implants: results from bone grafting to delivery of the final fixed prosthesis. J Oral Maxillofac Surg. 2008;66(4):780-786.

6. Collins TA, Brown GK, Johnson N, Massey JA, Nunn BD. Team management of atrophic edentulism with autogenous inlay, veneer, and split grafts and endosseous implants: case reports. Quintessence Int. 1995;26(2):79-93.

7. Graziani F, Donos N, Needleman I, Gabriele M, Tonetti M. Comparison of implant survival following sinus floor augmentation procedures with implants placed in pristine posterior maxillary bone: a systematic review. Clin Oral Implants Res. 2004;15(6):677-682.

8. Hallman M, Hedin M, Sennerby L, Lundgren S. A prospective 1-year clinical and radiographic study of implants placed after maxillary sinus floor augmentation with bovine hydroxyapatite and autogenous bone. J Oral Maxillofac Surg. 2002;60(3):277-284; discussion 285-286.

9. Jensen SS, Terheyden H. Bone augmentation procedures in localized defects in the alveolar ridge: clinical results with different bone grafts 
and bone-substitute materials. Int J Oral Maxillofac Implants. 2009;24 Suppl:218-236.

10. Keller EE. Reconstruction of the severely atrophic edentulous mandible with endosseous implants: a 10-year longitudinal study. J Oral Maxillofac Surg. 1995;53(3):305-320.

11. Wallace SS, Froum SJ. Effect of maxillary sinus augmentation on the survival of endosseous dental implants. A systematic review. Ann Periodontol. 2003;8(1):328-343.

12. Widmark G, Andersson B, Andrup B, Carlsson GE, Ivanoff CJ, Lindvall AM. Rehabilitation of patients with severely resorbed maxillae by means of implants with or without bone grafts. A 1-year follow-up study. Int J Oral Maxillofac Implants. 1998;13(4):474-482.

13. Isaksson $S$, Alberius P. Maxillary alveolar ridge augmentation with onlay bone-grafts and immediate endosseous implants.

J Craniomaxillofac Surg. 1992;20(1):2-7.

14. Jensen OT, Shulman LB, Block MS, lacono VJ. Report of the Sinus Consensus Conference of 1996. Int J Oral Maxillofac Implants. 1998;13 Suppl:11-45.

15. Jaffin RA, Berman CL. The excessive loss of Branemark fixtures in type IV bone: a 5-year analysis. J Periodontol. 1991;62(1):2-4.

16. Friberg $B$, Jemt $T$, Lekholm U. Early failures in 4,641 consecutively placed Branemark dental implants: a study from stage 1 surgery to the connection of completed prostheses. Int J Oral Maxillofac Implants. 1991;6(2):142-146.

17. Schramm A, Gellrich NC, Schimming $R_{t}$ Schmelzeisen R. Computer-assisted insertion of zygomatic implants (Brånemark system) after extensive tumor surgery. Mund Kiefer Gesichtschir. 2000;4(5):292-295.

18. Miglioranca RM, Coppede A, Dias Rezende $\mathrm{RC}$, de Mayo T. Restoration of the edentulous maxilla using extrasinus zygomatic implants combined with anterior conventional implants: a retrospective study. Int J Oral Maxillofac Implants. 2011;26(3):665-672.

19. Aparicio C, Manresa C, Francisco K, Claros P, Alandez J, Gonzalez-Martin O, Albrektsson T. Zygomatic implants: indications, techniques and outcomes, and the zygomatic success code. Periodontol 2000. 2014;66(1):41-58.

20.Bedrossian E, Stumpel L, 3rd, Beckely ML, Indresano T. The zygomatic implant: preliminary data on treatment of severely resorbed maxillae. A clinical report. Int $J$ Oral Maxillofac Implants. 2002;17(6):861-865.

21. Bothur S, Jonsson G, Sandahl L. Modified technique using multiple zygomatic implants in reconstruction of the atrophic maxilla: a technical note. Int J Oral Maxillofac Implants. 2003;18(6):902-904.

22. Bedrossian E. Rehabilitation of the edentulous maxilla with the zygoma concept: a 7-year prospective study. Int $\mathrm{J}$ Oral Maxillofac Implants. 2010;25(6):1213-1221.
23.Celletti R, Pameijer $\mathrm{CH}$, Bracchetti G, Donath K, Persichetti G, Visani I. Histologic evaluation of osseointegrated implants restored in nonaxial functional occlusion with preangled abutments. Int J Periodontics Restorative Dent. 1995;15(6):562573.

24. Mozzati M, Monfrin SB, Pedretti G, Schierano G, Bassi F. Immediate loading of maxillary fixed prostheses retained by zygomatic and conventional implants: 24-month preliminary data for a series of clinical case reports. Int J Oral Maxillofac Implants. 2008;23(2):308-314.

25. Aparicio C, Ouazzani W, Aparicio A, Fortes V, Muela R, Pascual A, Codesal M, Barluenga N, Franch M. Immediate/Early loading of zygomatic implants: clinical experiences after 2 to 5 years of follow-up. Clin Implant Dent Relat Res. 2010;12 Suppl 1:e77-82.

26. Huang W, Wu Y, Zou D, Zhang Z, Zhang C, Sun J, Xu B, Zhang Z. Long-term results for maxillary rehabilitation with dental implants after tumor resection. Clin Implant Dent Relat Res. 2014;16(2):282-291.

27. Higuchi KW. The zygomaticus fixture: an alternative approach for implant anchorage in the posterior maxilla. Ann R Australas Coll Dent Surg. 2000;15:28-33.

28. Pham AV, Abarca M, De Mey A, Malevez C. Rehabilitation of a patient with cleft lip and palate with an extremely edentulous atrophied posterior maxilla using zygomatic implants: case report. Cleft Palate Craniofac J. 2004;41(5):571-574.

29. de Santis D, Trevisiol L, Cucchi A, Canton LC, Nocini PF. Zygomatic and maxillary implants inserted by means of computer-assisted surgery in a patient with a cleft palate. J Craniofac Surg. 2010;21(3):858-862.

30. Kuabara MR, Ferreira EJ, Gulinelli JL, Panzarini SR. Use of 4 immediately loaded zygomatic fixtures for retreatment of atrophic edentulous maxilla after complications of maxillary reconstruction. J Craniofac Surg. 2010;21(3):803-805.

31. Brånemark PI, Grondahl K, Ohrnell LO, Nilsson P, Petruson B, Svensson B, Engstrand P, Nannmark U. Zygoma fixture in the management of advanced atrophy of the maxilla: technique and long-term results. Scand J Plast Reconstr Surg Hand Surg. 2004;38(2):70-85.

32. Aparicio C. A proposed classification for zygomatic implant patient based on the zygoma anatomy guided approach (ZAGA): a cross-sectional survey. Eur J Oral Implantol. 2011;4(3):269-275.

33. Boyes-Varley JG, Howes DG, Lownie JF, Blackbeard GA. Surgical modifications to the Branemark zygomaticus protocol in the treatment of the severely resorbed maxilla: a clinical report. Int J Oral Maxillofac Implants. 2003;18(2):232-237.

34. Schmidt BL, Pogrel MA, Young CW, Sharma A. Reconstruction of extensive maxillary defects using zygomaticus implants. J Oral Maxillofac Surg. 2004;62(9 Suppl 2):82-89. 
35. Balshi SF, Wolfinger GJ, Balshi TJ. A retrospective analysis of 110 zygomatic implants in a single-stage immediate loading protocol. Int J Oral Maxillofac Implants. 2009;24(2):335-41.

36. Pi Urgell J, Revilla Gutierrez V, Gay Escoda CG. Rehabilitation of atrophic maxilla: a review of 101 zygomatic implants. Med Oral Patol Oral Cir Bucal. 2008;13(6):E363-370.

37. Aparicio C, Ouazzani W, Garcia R, Arevalo $X$, Muela $\mathrm{R}$, Fortes V. A prospective clinical study on titanium implants in the zygomatic arch for prosthetic rehabilitation of the atrophic edentulous maxilla with a follow-up of 6 months to 5 years. Clin Implant Dent Relat Res. 2006;8(3):114-122.

38. Al-Nawas B, Wegener J, Bender C, Wagner W. Critical soft tissue parameters of the zygomatic implant. J Clin Periodontol. 2004;31(7):497-500.

39. Davo R, Malevez C, Rojas J. Immediate function in the atrophic maxilla using zygoma implants: a preliminary study. J Prosthet Dent. 2007;97(6 Suppl):S44-51.

40. Maló P, Nobre M, Lopes A, Francischone C, Rigolizzo $M$. Three-year outcome of a retrospective cohort study on the rehabilitation of completely edentulous atrophic maxillae with immediately loaded extra-maxillary zygomatic implants. Eur J Oral Implantol. 2012;5(1):3746.

41. Vrielinck L, Politis C, Schepers S, Pauwels M, Naert I. Image-based planning and clinical validation of zygoma and pterygoid implant placement in patients with severe bone atrophy using customized drill guides. Preliminary results from a prospective clinical follow-up study. Int J Oral Maxillofac Surg. 2003;32(1):7-14.

42. Farzad P, Andersson L, Gunnarsson S, Johansson B. Rehabilitation of severely resorbed maxillae with zygomatic implants: an evaluation of implant stability, tissue conditions, and patients' opinion before and after treatment. Int J Oral Maxillofac Implants. 2006;21(3):399-404.

43. Bedrossian E, Rangert B, Stumpel L, Indresano T. Immediate function with the zygomatic implant: a graftless solution for the patient with mild to advanced atrophy of the maxilla. Int J Oral Maxillofac Implants. 2006;21(6):937-942.

44. Chow J, Wat $P$, Hui E, Lee $P$, Li W. A new method to eliminate the risk of maxillary sinusitis with zygomatic implants. Int J Oral Maxillofac Implants. 2010;25(6):1233-1240.

45. Kahnberg KE, Henry PJ, Hirsch JM, Ohrnell LO, Andreasson L, Brånemark PI, Chiapasco M, Gynther G, Finne K, Higuchi KW, Isaksson S, Malevez C, Neukam
FW, Sevetz E Jr, Urgell JP, Widmark G, Bolind P. Clinical evaluation of the zygoma implant: 3-year follow-up at 16 clinics. J Oral Maxillofac Surg. 2007;65(10):20332038.

46. Zwahlen RA, Gratz KW, Oechslin CK, Studer SP. Survival rate of zygomatic implants in atrophic or partially resected maxillae prior to functional loading: a retrospective clinical report. Int J Oral Maxillofac Implants. 2006;21(3):413-20.

47. Maló $P$, de Araújo Nobre M, Lopes A, Ferro A, Moss S. Extramaxillary surgical technique: clinical outcome of 352 patients rehabilitated with 747 zygomatic implants with a follow-up between 6 months and 7 years. Clin Implant Dent Relat Res. 2015;17 Suppl 1:e153-162.

48. Aparicio C, Ouazzani W, Hatano N. The use of zygomatic implants for prosthetic rehabilitation of the severely resorbed maxilla. Periodontol 2000. 2008;47:162-171.

49. Schierano G, Canuto RA, Navone R, Peirone $B$, Martinasso G, Pagano M, Maggiora M, Manzella $C$, Easton M, Davit A, Trombetta A, Amedeo S, Biolatti B, Carossa S, Preti G. Biological factors involved in the osseointegration of oral titanium implants with different surfaces: a pilot study in minipigs. J Periodontol. 2005;76(10):1710-1720.

50. Glauser R, Lundgren AK, Gottlow J, Sennerby L, Portmann M, Ruhstaller P, Hämmerle CH. Immediate occlusal loading of Brånemark TiUnite implants placed predominantly in soft bone: 1-year results of a prospective clinical study. Clin Implant Dent Relat Res. 2003;5 Suppl 1:47-56.

51. Aparicio C, Manresa C, Francisco K, Ouazzani W, Claros P, Potau JM, Aparicio A. The long-term use of zygomatic implants: a 10-year clinical and radiographic report. Clin Implant Dent Relat Res. 2014;16(3):447-459.

52. Fernandez H, Gomez-Delgado A, TrujilloSaldarriaga S, Varon-Cardona D, Castro-Nunez J. Zygomatic implants for the management of the severely atrophied maxilla: a retrospective analysis of 244 implants. J Oral Maxillofac Surg. 2014;72(5):887-891.

53. Davo R. Zygomatic implants placed with a two-stage procedure: a 5-year retrospective study. Eur J Oral Implantol. 2009;2(2):115-124. 54. Stievenart M, Malevez C. Rehabilitation of totally atrophied maxilla by means of four zygomatic implants and fixed prosthesis: a 6-40-month follow-up. Int J Oral Maxillofac Surg. 2010;39(4):358-363. 

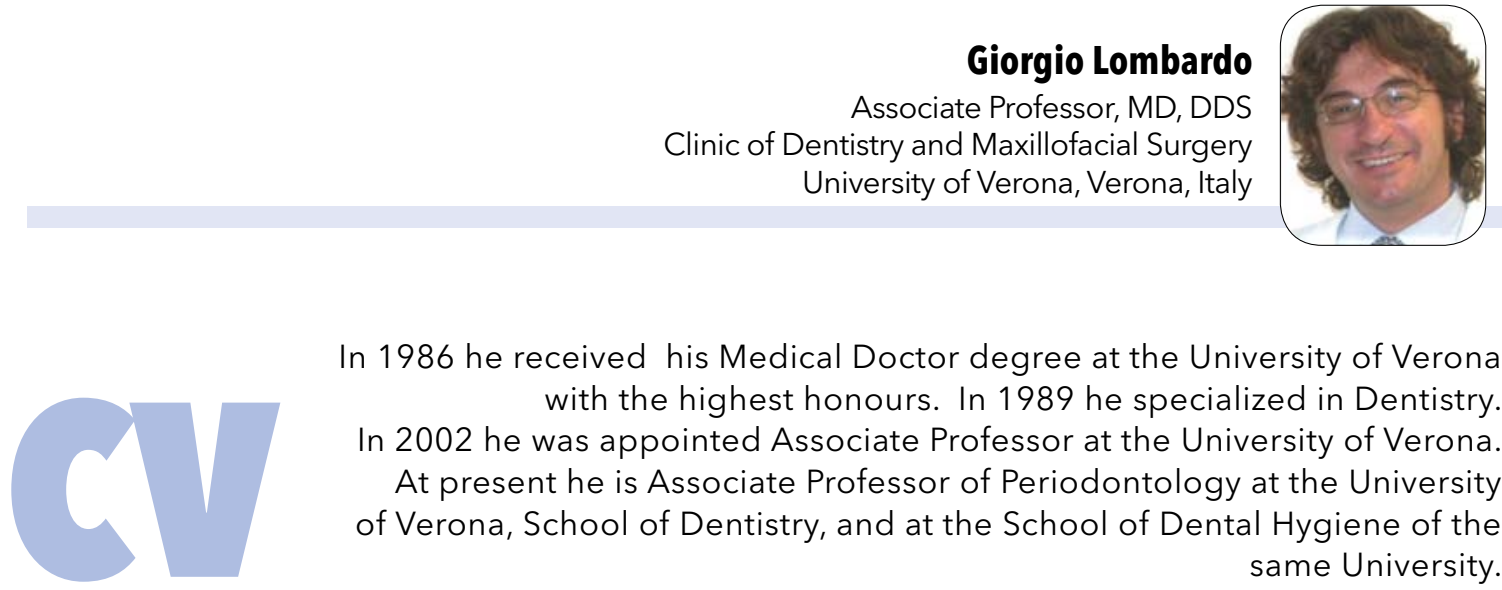

In 1986 he received his Medical Doctor degree at the University of Verona with the highest honours. In 1989 he specialized in Dentistry. In 2002 he was appointed Associate Professor at the University of Verona.

At present he is Associate Professor of Periodontology at the University of Verona, School of Dentistry, and at the School of Dental Hygiene of the same University.

Director of the Postdoc Master Program in Periodontics. Member of the Italian and European Society of Periodontology. Author of articles in peer-reviewed journals.

Private practice limited to Periodontics.

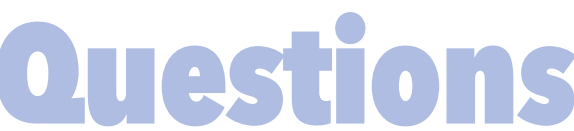

\section{In the Zygomatic Success Code, criterion D, which of the following represents the Condition III?:}

a. $0 \mathrm{~mm} \leq \mathrm{D} \leq 6 \mathrm{~mm}$

b. $6 \mathrm{~mm}<\mathrm{D} \leq 10 \mathrm{~mm}$

c. $10 \mathrm{~mm}<\mathrm{D} \leq 15 \mathrm{~mm}$

$\square \mathrm{d} . \quad \mathrm{D}>15 \mathrm{~mm}$

\section{What was the survival rate shown by many studies?:}

a. $100 \%$

ab. $80 \%$

c. $60 \%$

ad. $40 \%$

\section{In the management of an atrophic maxilla zygomatic implants are ....?:}

$\square$ a. The only treatment solution

$\square$ b. Not an effective alternative

c. Not a therapeutic choice

$\square \mathrm{d}$. An effective alternative and, in some cases, the only treatment solution

\section{In the Zygomatic Success Code, criterion A, which of the following represents the} Condition 1?:

a. Light clinical mobility

$\square$ b. Clear clinical mobility = no evidence of disintegration of the apical part of the implant or rotation

$\square$ c. Clear clinical mobility = evidence of disintegration of the apical part of the implant

$\square d$. No mobility 